\title{
Masalah Mafia Peradilan dan Penanggulangannya
}

\author{
Artidjo Alkostar
}

\begin{abstract}
In criminology perspectives, there many factors can be identified as the stimulant condition the emerge of melajudicial action. One of the is making relation between who uphold the law and the party involved. Ideally, the two parties in relation of case must be professional but in reality, the pattern emerge is transactional. The serious implication of such relation pattem cause the negative impacts for the aspects of having nation and having country. Logically, by the glow of mela practice on judicial, so the effort of prevention must be put into action immediately. This prevention is be approached by not only law enforcement aspect but it must be spreaded widely till any kinds of controlling from the govemment board, and it makes more society advocates who those suffered by the law enforcement.
\end{abstract}

\section{Pendahuluan}

Mafia peradilan sesungguhnya merupakan "penyakit" yang menghinggapi hampir semu peradilan negara-negara di dunia ini. Dalam konteks Indonesia, persoalannya menjadi. sangat serius karena fenomena mafia tersebut terlanjur berkembang secara sistemik dan terkesan sebagai suatu "budaya."

Dalam perspektif kriminologis, ada banyak faktor yang dapat diidentifikasi sebagai pendorong kondisi timbulnya praktek mafia peradilan. Salah satu hal terpenting ialah karena telah terjadinya perubahan sifat hubungan antara aparat penegak hukum dengan pihak yang berperkara, dari yang seharusnya bersifat profesional menjadi transaksional. Implikasi dari perubahan sifat hubungan yang seperti ini adalah tumbuhnya persepsi yang mempertanyakan apakah pengadilan itu milik orang yang benar dan jujur ataukah milik orang yang mampu "membeli" hukum dan harga diri aparatnya?

Tidak diragukan lagi bahwa praktek peradilan yang dikendalikan oleh mafia, akan menimbulkan berbagai dampak negatif yang merusak sendisendi kehidupan berbangsa dan bernegara. Seperti macetnya proses demokratisasi, tejadinya iklim diskriminasi hukum yang merupakan pelanggaran hak asasi manusia (HAM) universal, hancumya martabat peradilan (contempt of count), timbulnya situasi berupa ketidakpercayaan publik terhadap hukum (eigen richting) dan lain sebagainya. 


\section{Konstelasi Pihak-pihak yang Terlibat dalam Proses Peradilan}

Pelaksanaan peradilan tidak pernah berproses di ruang hampa, tetapi selalu berlangsung dengan keterlibatan faktor-faktor perangkat hukum, mental aparat penegak hukum, kondisi, sosial politik, keadaan ekonomi, tersedianya fasilitator bantuan hukum, dan tingkat pendidikan masyarakat. Pelaksanaan peradilan secara sadar selalu menuntut dipenuhinya prosedur-prosedur yang ditentukan dalam hukum acara. Tidak terpenuhinya prosedur baku yang diatur dalam hukum acara, dapat mengakibatkan proses peradilan itu menjadi batal dan tidak sah.

Di dalam proses peradilan, pihak-pihak yang terlibat aktif dalam prosedur-prosedur berperkara, jka perkara pidana yaitu 1. terlapor/ teradu, 2. pelapor/pengadu, 3. polisi, 4. pengacara, 5. jaksa, 6. panitera, 7. hakim. Sedangkan dalam perkara perdata/niaga/TUN, melibatkan penggugat, tergugat, pengacara, panitera, dan hakim. Para penegak hukum yaitu Polisi, Jaksa dan Hakim mempunyai mandat hukum yang diberikan oleh undang-undang untuk melaksanakan tindakan hukum seperti. kewenangan untuk mengeledah, menangkap dan menahan bagi Polisi. Mandat hukum untuk menyidik (korupsi), menahan dan menentukan tuntutan hukum oleh Jaksa. Mandat hukum untuk menahan, mengadili dan menjatuhkan hukuman oleh hakim. Setiap mandat hukum yang diberikan kepada para penegak hukum itu, wajib dilaksanakan secara profesional. Dalam arti pula, perintah hukum itu harus dilaksanakan berdasarkan ketentuan hukum, dengan bekal legal technical capacity yang cukup, dan dengan integritas moral yang tinggi. Dalam konteks mafia peradilan di Indonesia tahun 2000-an, munculnya istilah "Pengacara Hitam atau dark lawyer tiddak dapat dipisahkan dari kelabunya dunia peradilan yang melibatkan peran negatif dari sebagian pengacara yang melakukan malpraktek dan perbuatan culas lainnya.

Setiap momentum atau terminal kekuasaan hukum untuk menangkap/menyidik, menuntut dan menjatuhkan hukuman itu akan terjadi bias atau penyimpangan apabila amanat hukum itu tidak dilaksanakan secara profesional, artinya tugas hukum itu tidak berproses secara benar, karena ada faktor godaan dan tantangan (ancaman), sehingga terjadi bias atau penyimpangan dari standar baku penegakan hukum. Bias nurani penegak hukum akan selalu menimbulkan Kidung Derita bagi pencari keadilan sejati. Bias atau penyimpangan arah penegakan keadilan itu terjadi karena adanya "hubungan khusus" dan kesepakatan antara yang terlibat perkara dengan penegak hukum. Dalam hubungan ini, mafial peradilan terjadi karena hubungan profesional yang seharusnya terjadi antara penegak hukum dengan pihak yang berperkara berubah menjadi hubungan transaksional.

Pertanyaan rakyat awam dan desah nurani paling dalam, dalam bernegara siapa yang menjadi pemilik pengadilan? orang yang benar dan jujur-kah atau orang yang dapat membeli harga diri penegak hukum. Dalam bukunya Money and Justice, Who Owns the Courts? Louis G. Forer, ${ }^{1}$ memunculkan pertanyaan who owns the courts? (siapa yang memiliki pengadilan?). Selanjutnya dia

\footnotetext{
'Louis G Forer, Money and Justice, Who Owns the Courts (Norton Paperback, 1986), hlm 14.
} 
menjawab sendiri dengan mengatakan -the question- raises not only legal but also moral, political and philosophical issues. Jadi, pertanyan ini sebenarnya merupakan insinuasi sinis bagi para lawyer, jaksa, hakim yang mempertanyakan kredibilitas moral profesi hukum.

Di samping dapat mengundang citra jelek di mata internasional, penyakit korupsi juga merugikan perekonomian dan keuangan negara. Lebih dari itu, dunia peradilan juga mendapat imbas wajah korupsi. Untuk itu di samping dituntut: adanya perilaku hukum positif, faktor pembudayaan support positif bagi pemberi hukum yang adil, secara psikologis dapat bermanfaat jika dibudayakan dalam tata hubungan sosial. Dalam bukunya Simple Justice, Richard Kluger mengemukakan beberapa tokoh 'Pemberi Hukum Yang Adil the east and west panels featute, among other favorites from someone's bloated nation of the mythicized past, the "Genili of Wisdom and Statecraft", a winged figure tagged "Divine Inspiration" and a cast of opposing contenders"Corruption", "Deceit", and "Despotic Power" versus "Charity", "Peace", "Harmony", and "Security". The north and south panels offer analtime, all-star cast of great lawgivers, including Hamurabi, Solomon, Conficius, Mohammed, Augustus, Justinian, Charlemagne, King John (which seems like crediting Moses for parting the Red Sea), St. Louis, Blackstone, Napoleon and John Marshall I the only thing unequely American about the room, except for the large flag in the corner. ${ }^{2}$ Nama-nama Penegak Hukum yang Agung Amerika Serikat, adalah para tokoh pembuat tonggak sejarah peradaban melalui pembangunan dan penegakan hukum. Dalam konteks penegakan keadilan hukum terjadi pemisahan yang jelas antara korupsi, penipuan (ketidakjujuran), memfitnah, penyalahgunaan kekuasaan ditempatkan pada posisi diametrikal dengan kedermawanan, perdamaian, harmoni dan keamanan.

\section{Gagasan Penghapusan Mafia Peradilan}

Dalam menggagas dan upaya menghapuskan Mafia Peradilan, menuntut adanya revitalisasi peran signifikan, agar terjadi hubungan partnership yang dinamis dan kritis antar penegak hukum seperti hakim, jaksa, pengacara, polisi dan masyarakat pecinta keadilan, sehingga tercipta adanya kondisi penegakan hukum yang transparan dan bermartabat. Penataan hubungan partnership ini harus dapat membangun hubungan institusional kredibel dan mencegah terjadinya hubungan yang kolutif.

Kontrol intern dan ekstern terhadap institusi penegak hukum ini merupakan kebutuhan pokok bagi kredibilitas dan perkembangan lembaga penegak hukum. Kontrol intern termasuk tindakan disiplin, penegakan kode etik, eksaminasi, pengawasan, beserta penjatuhan sanksi dan pemberian promosi. Sedangkan kontrol ekstern termasuk proses hukum, peran KPKPN, Pers, ICW, Ombusman, Polisi Watch, Judicial Watch dan lain-lain. Tanpa didukung oleh adanya kredibilitas, eksistensi lembaga penegak hukum akan digerogoti oleh virusvirus Mafia Peradilan, sehingga pada gilirannya akan kehilangan legimitasinya di mata. rakyat secara nasional, maupun di mata komunitas

${ }^{2}$ Richard Kluger, Simple Justice (1976), hlm 564 
internasional. Masuknya unsur luar ke dalam institusi penegak hukum seringkall disebabkan oleh kelemahan dan kenaifan lembaga penegak hukum (aparat) itu sendiri, misalnya munculnya hal-hatyang bersifat ad hoc. Artinya aparat penegak hukum itu sendiri tidak tahu, atau tidak mau tahu tentang kelemahannya, sehingga lalu menimbulkan ketidakpercayaan masyarakat terhadap integritas moral dan kemampuan institusional.

Secara umum, segala bentuk pelecehan dan tindakan merendahkan martabat peradilan sebagai contempt of court. Hubungan transaksional dalam proses peradilan sehingga menimbulkan bias arah penegakan hukum yang tercakup dalam kualifikasi mafia peradilan pada dasarnya juga termasuk pelecehan peradilan atau contempt of court. Jadi contempt of court tidak hanya dapat dilakukan oleh mass media, dan masyarakat umum, tapi juga dapat dilakukan oleh aparat penegak hukum itu sendiri, Jika tindakan penegak hukum tersebut merendahkan martabat peradilan. Seperti konstatasi Overbeck dan Pullen: Contempt of court is a very old-and very new-legal problem for journalists. Basically, it originated with the idea that a judge should be able to control the decorum of the courtroom, and should have the authority to summarily punish those who violate that decorum. American judges have had contempt powers ever since the founding of the republic, and English and colonial judges exercised the power considerably before that ${ }^{3}$ Peran hakim dalam menjaga dan menegakkan martabat pengadilan tidak hanya dalam hal menangani ketertiban dàlam ruang pengadilan, tetapi juga secara luas menyangkut penjagaan martabat dalam hal agar tidak terjadi pelecehan pengadilan dalam bentuk suap atau mafia peradilan dalam berbagai corak dari variasinya.

Dalam upaya membangun Peradilan yang berwibawa dan tidak terjangkit Mafia Peradilan, menuntut adanya kredibilitas personal dan integritas moral kelembagaan. Untuk itu, diperlukan adanya kualifikasi standar kemampuan intelektual para penegak hukum yang menyangkut spirit keilmuan, semangat inovasi dan memiliki komitmen terhadap keadilan sebagai penyangga tegaknya peradaban. Dalam hubungan ini, perlu dirintis berdirinya Continuing Legal Education bagi para penegak hukum, sehingga para penegak hukum memiliki visi yang sama tentang hakikat penegakan keadilan. Keberadaan CLE (Continuing Legal Education) akan dapat menyelaraskan prosedur, tujuan dan nilai hakiki dari penegakan hukum yang sejatinya di kalangan penegak hukum. Apalagi sistem penegakan hukum kita (Indonesia) bidakmenganut precedence dan belum menggunakan Integrated Criminal Justice System. Dalam arti pula, dalam upaya menghapus Mafia Peradilan kita perlu membangun sistem penegakan yang tidak memberi peluang terjadinya penyelewengan hukum yang merupakan salah satu bentuk dari Mafia Peradilan.

Birokrasi yang berbelit-belit dan tidak transparan berpotensi untuk menumbuhkan mafia peradilan. Karena korupsi tumbuh subur dalam suasana gelap (tidak transparan), sehingga lalu muncul pasar gelap keadilan dalam bentuk hubungan transaksional kolutif.

\footnotetext{
${ }^{3}$ Wayne Overbeck, Rick D. Pullen, Major Principles Of Media Law (CBS College Publishing, 1985), hlm 202.
} 
Lebih dari itu, gelapnya cuaca peradilan juga dapat disebabkan oleh banyaknya polusi peradilan. Seperti yang pernah diungkapkan oleh Charles R. Ashman ${ }^{4}$ dalam bukunya The Finest Judges Money Can Buy And Forms of Judicial Pollution, yang mengatakan bahwa keadilan di Amerika Serikat tersumbat oleh adanya judicial pollution. Polusi peradilan ini dalam prakteknya tidak hanya berupa korupsi yang sekali-kali terjadi, tetapi juga menyangkut pola utusan yang bermuatan conflicts of interest, penyuapan, penyalahgunaan kewenangan, nepotisme yang memuakkan, pembayaran yang bersifat merusak sistem yang rasional.

Lubang-lubang hukum lain yang dapat dimasuki oleh Mafia Peradilan adalah penerapan asas oportunitas bukan asas lehalitas, juga masih mewarisi feodalisasi hukum yang pernah dibudayakan oleh rezim orde baru. Padahal, tegaknya supremasi hukum selalu menuntut budaya egalitarian spirit kerakyatan dan komitmen terhadap Hak Asasi Manusia (HAM). Keadilan adalah bahasa universal yang tidak dapatedisekat oleh perbedaan suku, agama, kebangsaan maupun keyakinan politik. Begitu pula tentang empati terhadap. HAM, karena penegakan HAM berarti berbicara tentang Anak Cucu Adam, sehingga penegakan tidak memandang adanya. perbedaan suku, agama, nasionalisme maupun keyakinan politik. Untuk itu, yang harus ditanamkan bagi penegak hukum adalah pemahaman bahwa menegakkan keadilan dan menghapus Mafia Peradilan berarti menegakkan peradaban dan martabat kemanusiaan. Pada saat yang sama, melakukan transaksi hukum terlibat Mafia Peradilan, berarti menista martabat kemanusiaan, yang pada gilirannya merusak Mikro Kosmos dan Makro Kosmos.

Munculnya fenomena Mafia Peradilan di indonesia merupakan bagian dari krisis hukum multi dimensi yang berlangsung sejak tahun 1980-an masa Orde Baru. Krisis hukum tersebut berjangkit baik pada tataran Kosmos, Logos, Teknologos dan Real Every Day Life di mana Mafia Peradilan dirasakan langsung oleh rakyat yang tidak memiliki proteksi politik maupun ekonomi. Akibatnya diskresi-diskresi hukum atau pemanfaatan "area kelabu" dalam hanya dinikmati oleh barang siapa yang mau, mampu dan tega "memperkosa" Dewi Keadilan dengan cara mempergunakan kekuasaan politik maupun kekuatan ekonomi. Sejak terjadi chaos, bangsa kita memang belum pernah melahirkan arsitek hukum nasional yang handal, dan secara institusional pembangunan hukum di negara kita belum pernah dipikirkan secara serius. Memang sejak zaman penjajahan Belanda, bangsa kita tidak pernah dilatih untuk merancang bangun fondasi nasional dari suatu șistem hukum yang utuh. Padahal sebagai negara besar Indonesia memerlukan The Great Lawgiver, karena pembangunan hukum merupakan bagian terpenting dari pembangunan masyarakat' beradab.

Penyimpangan putusan pengadilan yang dapat mengundang Mafia Peradilan, dapat juga diminimalisasi melalui Komisi Judisial. Dalam amandemen UUD 1945 dan juga disebut dalam RUU amandemen terhadap UU No. 14 Tahun 1985 diperkenalkan adanya Komisi Judisial yang antara lain dirancang untuk memilih atau melakukan Fit and Proper Test terhadap calon Hakim Agung. Sifat

\footnotetext{
${ }^{4}$ Charles R Ashman, The Finest Judges Money Can Buy (Nash Publishing, Los Angeles, 1973), hlm 3.
} 
kemandirian yang menyangkut susunan, kedudukan dan keanggotaannya diatur dengan undang-undang. Dan sebagai perbandingan, di negara bagian New South Wales, Australia, tugas dari Judicial Commission antara lain memeriksa pengaduan-pengaduan yang menyangkut para hakim. Lebih dari itu, fungsi utama dari Judicial ini adalah membantu pengadilan untuk mencapai konsistensi dalam pendekatan pemidanaan terhadap pelanggar hukum. Tujuan Komisi dalam hal ini ialah untuk mengurangi ketidakadilan dalam penghukuman, mengembangkan penghukuman yang efisien secara umum, mengurangi jumlah banding terhadap putusan dan mengurangi penundaan-penundaan yang sering terjadi dalam hukum acara. Di Indonesia fenomena penundaan penjatuhan vonis sering terjadi. Penundaan penentuan vonis yang disengaja dan membuka peluang terjadinya mafia peradilan, pernah dianekdotkan dengan istilah TOD atau Tunggu Orangnya Datang. Padahal penundaan penentuan keadilan pada dasarnya sering dianggap sebagai sudah merupakan ketidakadilan.

\section{Prospek Langkah Ke Depan}

Upaya menghapuskan Mafia Peraḍilan merupakan kewajiban asasi masyarakat bangsa Indonesia, karena Mafia Peradilan merupakan tindakan amoral dan asosial yang mènimbulkan krisis multi-dimensi bagi rakyat, menurunkan martabat bangsa dan merendahkan citra negara di mata dunia internasional. Lebih dari itu, Mafia Peradilan merupakàn musuh bangsa beradab.
Pemerintah Ronald Reagan, pernah terjadi tensi dalam hal pengusulan Calon Hakim Agungyang telah diajukan oleh Presiden Ronald Reagan. Tetapi yang jelas Mahkamah Agung AS seperti kata Lasser "The supreme court's extraordinany power to interpret and enforce the constitution refrects the longstanding American commitment to the ideas of limited government and the rule of law. ${ }^{5}$ Jadi, kekuasaan luar bisa dari Mahkamah Agung AS dalam menafsirkan dan melaksanakan konstitusi merupakan komitmen yang sudah berjalan lama dalam rakyat Amerika Serikat terhadap gagasam limited government dan tegaknya hukum.

Di Amerika Serikat fenomena korupsi tidak sistemik karena tidak menyatu dalam sistem pelayanan publik, dan juga di Korea Selatan karena masi ada kontrol sosial dan kontrol hukum, bekas presiden dan anak presiden tidak dibuat menjadi kebal hukum di Korea Selatan. Sedangkan di negara kita, lembaga sosial politk dan hukum tidak memiliki daya kontrol; bahkan terjadi krisis kewibawaan institusi. Dengan adanya sinar kebenaran moral hukum .dan cahaya transformasi demokrasi yang sehat, maka korupsi di negara tersebut (di AS dan Korea) tidak sampai sistemik, korupsi tidak sampai menjadi kanker yang akut menggerogoti jaringan birokrasi. Di negara kita Indonesia, perilaku hukum para pejabat dan elit politik dan ekonomi yang bersifat koruptif, banyak terpublikasi dengan tanpa rasa bersalah, kendatipun UU Korupsi mengancam pidana seumur hidup bagi koruptor. Dan dalam proses peradilan, hakim dapat memberlakukan asas

${ }^{5}$ William Lasser, The Limit of Judicial Power (The University of North Carolina Press, 1988), hlm 249. 
pembuktian, terbalik. Hal ini sebenarnya merupakan fasilitas: hukum dalam teknis mengungkapkan keterlibatan seorang atau berangsiapa disangka atau didakwa terlibat dalam perbuatan korupsi. Masalah pembuktian terbalik ini berada dalam kawasan teknologos.

Aristokrasi para Konglomerat Indonesia telah lama menggejala, karena proses pembangunan pada masa orde baru hanya menonjolkan dimensi pertumbuhan dan stabilitas, bukan pemerataan keadilan. Fenomena yang demikian akan menjadi kendala yang menghalangi pencapaian tujuan negara seperti yang tertuang dalam UUD 1945, yaitu masyarakat yang adil dan makmur. - Mengesampingkan atau menunda penerapan fungsi hukum, yaitu pemerataan keadilan ekonomi, politik dan hukum, merupakan salah satu ciri masyarakat bangsa yang aristokratis dan/atau otoriter. Pemberdayaan hukum yang rasional dan responsif, merupakan salah satu determinan dalam mewujudkan clean government dan good governance. Eskalasi pencapaian pemerintahan yang bersih dan birokrasi yang baik, berkorelasi dengan fasilitas struktur hukum yang kuat dan berparadigma nilai yang jelas. Dalam hubungan ini relevansi yuridis ditingkatkannya Keppres №. 92 tahun 1996 menjadi undang-undang, akan memperkuat landasan pengembangan dimensi etis proses pembangunan. Jadi suatu pemerintahan yang kuat dan bersih harus dibangun dengan fundamental hukum yang kokoh.

Upaya menghapuskan Mafia Peradilan merupakan keniscayaan bagi bangsa bermartabat, karena Mafia Peradilan merusak sendi-sendi keadilan, kemanusiaan dan kepatutan dalam proses penegakan hukum. Mafia Peradilan adalah manifestasi dari sikap tidak ksatria dalam proses pertarungan hukum, dan hanya pantas dilakukan oleh pihak yang sengaja membutakan hati nuraninya sendiri. Perjalanan arah masa depan bangsa dan generasi muda menjadi tidak suram, karena tidak dipandu oleh hati nurani yang jujur dan peradaban yang jelas.

Kontrol terhadap Mafia Peradilan baik secara eksternal maupun internal institusi penegak hukum, merupakan bagian dari kesadaran etis bernegara dalam upaya mencapai supremasi hukum. Tegaknya supremasi hukummerupakan tiang pokok kohesi nasional persatuan bangsa. Tanpa adanya supremasi hukum, maka yang muncul adalah supremasi kekuatan politik dan/atau kekuasaan ekonomi yang dicapai dengan cara kerupsi pula.

Penegak hukum yang melakukan Mafia Peradilan berarti menista martabàt dirinya dan mengkhianati kepercayaan masyarakat yang melekat pada posisi sosio-profesionalnya sebagai pejabat publik. Untuk itu, upaya menghapuskan Mafia Peradilan disamping harus dinilai dari dalam diri penegak hukum itu sendiri, juga perlu diperluas aneka kontrol sosial dari lembaga non-pemerintah, serta memperbanyak advokasi masyarakat yang dirugikan oleh aparat penegak hukum yang harus menunjukkan public accountability. Dalam arti pula, pemerintah wajib menjamin adanya independent judiciany dan mempertebal tekad political willnya dalam upaya menghapuskan Mafia Peradilan yang selalu merusak martabat bangsa.

\section{Simpulan}

Terjadinya Mafia Peradilan merupakan manipulasi kebenaran hukum, yang berarti matinya akal sehat, karena dalam proses itu yang salah menjadi benar dan yang benar 
menjadi salah. Untuk itu adanya audit hukum terhadap penegak hukum yang terlibat Mafia Peradilan merupakan konsekuensi yuridis dari adanya tindakan malpraktek dan sikap tidak profesional dari aparat penegak hukum.

\section{Daftar Pustaka}

Ashman, Charles R. The Finest Judges Money

Can Buy, Los Angeles: Nash Publishing, 1973.

Bergman, Paul. TrialAdvocacy, St. Paul: West Publishing Co., 1989

Callison IP. Courts Of Injustice, New York: Twayne Publishers, 1956.

Dye Thomas R. Power And Society, belmont: Wadsworth Inc., 1983

Frankel, Marvin E. Partisan Justice, New York: Hill and Wang, 1980.

Forer, Louis G. Money and Justice, Who Owns the Courts?, Norton Paperback, 1986. Johnston, Michel. The Political Corruption and Public Policy in America, California: Brooks/Cole Publishing Company, 1982.
Lasser, William. The Limit of Judicial Power, The Supreme Court in American Politics, The University of North Carolina Press, 1988.

Pember, Don R. Mass Media Law, Brown \& Benchmark Publisher, 1997.

Reid, Sue Zilus. Criminal Law, Prentice. Hall, Englewood Cliffs, 1995.

Rider, Barry. Corruption : The Enemy Within, The Hagul: Kluwer Law International, 1997.

Schmidhauser, John R. Judge and Justice, The Federal Appellate Judiciary, Little Brown and Company, 1979.

Seagraue, Sterling. Dinaști Marcos, Korupsi Harta dan Kekuasaan di Filipina, Pustaka Jaya, 1996.

Strauss, Peter L. An Introduction to Administrative Justice in the United States, Carolina Academic Press, 1989.

Thirox, Jacques. Ethics, Theory and Practice, New Jersey: Prențce Hall, 1995

Warren, Kenneth F. Administrative Law, in the Political System, New Jersey: Prentice Hall, 1996. 